\title{
EVALUASI PEMENUHAN STANDAR MINIMAL SARANA DAN PRASARANA PENDIDIKAN ANAK USIA DINI
}

\author{
Elya Siska Anggraini $^{(1)}$ Lukeysia F. Batubara ${ }^{(2)}$ \\ (1) Dosen PG PAUD FIP UNIMED \\ (2) Mahasiswa Program Studi PG PAUD FIP UNIMED \\ Jln. Williem Iskandar Pasar V Medan Estate, Medan, Sumatera Utara, 20371 \\ Email : elyasiskaanggraini@unimed.ac.id
}

\begin{abstract}
Abstrak : Penelitian ini bertujuan untuk evaluasi pemenuhan standar minimal sarana dan prasarana di lembaga PAUD. Jenis penelitian yang digunakan adalah kualitatif deskriptif. Model evaluasi yang digunakan adalah model evaluasi ketimpangan (the discrepancy evaluation model). Pemilihan subyek menggunakan purposive sampling, dilanjutkan dengan Snow Ball Sampling. Pengumpulan data pada penelitian ini menggunakan metode observasi, wawancara dan dokumentasi. Dengan alat permainan edukatif dapat mencerdaskan anak, namun dengan memperhatikan mana alat yang mengandung nilai edukatif tinggi, dan mana alat permainan yang kurang efektif bagi perkembangan anak-anak. Jika dalam proses evaluasi ini di temukan beberapa jenis permainan yang kurang bermanfaat dalam perkembangan potensi anak, sebaiknya alat permainan tersebut di ganti dengan alat permainan edukatif yang lain.
\end{abstract}

Kata kunci : Evaluasi, Sarana Prasarana, PAUD 


\section{PENDAHULUAN}

Salah satu syarat suatu lembaga PAUD adalah diperlukan sarana dan prasarana pendidikan yang mendukung. Peraturan Pemerintah Nomor 19 Tahun 2005 tentang Standar Nasional Pendidikan pasal 42 ayat 2 yang menyatakan bahwa setiap satuan pendidikan wajib memiliki prasarana yang meliputi lahan, ruang kelas, ruang pimpinan satuan pendidikan, ruang pendidik, ruang tata usaha, ruang perpustakaan, ruang laboratorium, ruang bengkel kerja, ruang unit produksi, ruang kantin, instalasi daya dan jasa, tempat berolahraga, tempat beribadah, tempat bermain, tempat berkreasi, dan ruang/tempat lain yang diperlukan untuk menunjang proses pembelajaran yang teratur dan berkelanjutan. Lebih lanjut dijelaskan dalam Permendiknas 58 Tahun 2009 tentang Standar PAUD telah disebutkan mengenai prinsip dan persyaratan prasarana yang wajib dimiliki sebuah lembaga PAUD.

Standar sarana dan prasarana Pendidikan Anak Usia Dini yang seharusnya meliputi lahan, bangunan gedung yang didalamnya mencangkup ruang kelas, ruang guru, ruang kepala sekolah, ruang UKS, jamban serta didukung dengan adanya fasilitas permainan di dalam maupun luar ruangan, alat permaianan edukatif dan peralatan pendukung keaksaraan.

Namun fakta di lapangan menunjukan sarana dan prasarana belum sepenuhnya kondisinya memadai, banyak ruang belajar dan sarana belajar yang rusak. Sehingga kondisi tersebut akan berpengaruh pada ketidaklayakan, ketidak nyamanan pada proses belajar mengajar, juga akan berdampak pada keengganan dan sifat sepele/ ketidakpedulian orangtua untuk menyekolahkan anaknya ke lembaga paud. Masih banyak masyarakat, guru dan sekolah yang belum memahami sarana dan prasarana yang diperlukan oleh sebuah lembaga PAUD yang sesuai dengan kebutuhan anak serta belum mengetahui tentang cara pengelolaannya.

Berdasarkan pertimbangan di atas, maka perlu dilakukan evaluasi pemenuhan standar sarana dan prasarana. Melalui tulisan ini, penulis dapat memberikan gambaran tentang identifikasi kebutuhan sarana dan prasarana PAUD sesuai kategori usia anak dan perkembangannya serta standar pengelolaan sarana dan prasarana PAUD.

\section{KAJIAN TEORI}

a. Prasarana

Prasarana adalah bangunan Taman Kanak-Kanak. Menurut Ibrahim Bafadal (TT: 73), bangunan Taman Kanak-Kanak merupakan gedung Taman Kanak-Kanak yang di dalamnya berisi ruang belajar, ruang bermain baik di luar maupun di dalam, ruang perpustakaan, dan ruang-ruang lain yang letaknya melekat dengan Taman KanakKanak termasuk di dalamnya pekarangan, parit/got/selokan, dan kolam renang. Selain gedung, luas lahan atau luas tanah juga termasuk di dalam bangunan Taman KanakKanak. Sedangkan menurut Suyadi (2011: 178) pada dasarnya tidak ada standar baku yang mengikat tentang luas tanah untuk mendirikan gedung di Taman Kanak-Kanak. Ia mengatakan bahwa luas lahan menjadi akses ruang bermain dan mengembangkan kreativitas anak. Sehingga Suyadi (2011: 178) mengemukakan bahwa prasarana yang dimiliki oleh sekolah harus disesuaikan dengan jumlah anak.

Oleh karena itu sangat penting penyesuian ruang-ruang yang relevan untuk pembelajaran anak dengan jumlah anak.

b. Sarana

Sarana di Taman Kanak-Kanak meliputi:

1) Perabot Taman Kanak-Kanak/ Perabot Kelas

Perabot kelas adalah peralatan yang digunakan di dalam ruangan kelas. Menurut Tadkiroatun Musfiroh (2005), perabot kelas meliput meja dan kursi anak, papan tulis, loker anak tempat minum, dan meja guru yang dirancang aman, terjangkau anak, tidak tajam, dan bebas dari bahan berbahaya. Perabot dapat disusun dengan baik dan 
dapat dijangkau oleh anak. Penggunaan prabot yang menarik seperti di cat berwarnawarni sehingga anak lebih senang untuk belajar.

2) Alat Peraga

alat eraga yang digunakan di PAUD bisa beragam, seperti: miniatur hewan, manusia, pekerjaan, dan lain sebagainya.

Menurut Anggani Sudono (1995: 13), alat peraga merupakan semua alat yang digunakan oleh guru untuk menerangkan atau memperagakan materi yang akan disampaikan dalam proses pembelajaran.

3) Media Pembelajaran

Media pembelajaran PAUD juga beragam dari media pembelajaran sederhana yang dibuat oleh kreativitas guru sampai dengan media pembelajaran modern seperti: komputer, televisi, tape recorder dan lain sebagainya. Media pembelajaran dapat dikembangkan melalui oleh guru/ tenaga pendidik sesuai tema- tema PAUD. Contohnya: membuat media menebak buah-buahan untuk mengembangkan sosial emosional anak, membuat media flashcard dari kardus bekas, membuat media buka tutup botol untuk berhitung dan menemukan persamaan maupun perbedaan setiap botol, dan lain sebagainya. Sehingga media pembelajaran dapat mengembangkan daya imajinasi anak dalam proses pembelajaran.

4) Alat Permainan Edukatif

Alat permainan edukatif berfugsi untuk membantu aspek perkembangan anak usia dini. Alat permainan edukatif dirancang dengan aman, mudah digunakan dan sederhana serta terlihat menarik.

Di samping pendapat tersebut, Tadkiroatun Musfiroh (2005) juga menyatakan bahwa alat permainan edukatif (APE) merupakan alat yang dapat dimanfaatkan untuk kegiatan bermain anak serta memungkinkan anak untuk dapat bereksplorasi, aktif, dan kreatif. Terdapat dua jenis APE yaitu APE Tradisional dan APE Modern.

\section{APET}

APET (Alat Permainan Edukatif Tradisional) merupakan alat-alat permainan tradisional yang di lakukan secara turun-temurun. Contoh APET adalah egrang, baling-baling bamboo, tembak peluru bamboo dan lain-lain.

\section{APEM}

Variasi APE modern dapat kita jumpai di took-toko mainan anak. Contoh dari APEM adalah bricks dan leggo.

5) Sarana Sudut (Khusus Bagi Kelas/Sekolah yang Menggunakan Mode Pembelajaran Kelompok/Sudut)

Sarana sudut adalah sebuah sarana belajar secara berkelompok di ruangan kelas.. Sarana sudut terbagi menjadi lima, yaitu sudut ketuhanan atau sudut agama atau sudut iman dan taqwa, sudut kebudayaan, sudut pembangunan, sudut alam sekitar, serta sudut keluarga.

Sarana Prasarana Pembelajaran Kegiatan di bagi Menjadi 2 yaitu:

1. Sarana Prasarana Perangkat Pembelajaran Indoor

Contoh sarana prasarana indoor (di didalam ruangan) adalah bola, balok dengan berbagai bentuk, papan bermain, gambar-gambar bertema, dan lain-lain

2. Sarana Prasarana Perangkat Pembelajaran Outdoor

Contoh sarana prasarana indoor (di di luar ruangan) adalah jungkat-jungkit, ayunan, seluncuran, roda berputar, terowongan besar buatan dan lain sebagainya. Biasanya sarana prasarana outdoor banyak di temukan di depan gedung/ halaman sekolah PAUD.

Evaluasi Sarana Prasarana

Pelaksanaan evaluasi sarana prasarana oleh pihak sekolah dapat dilakukan dengan eveluasi diri. Yaitu, sekolah dapat melihat sendiri kondisi sarana prasarana yang dimiliki. Seperti kekurangan maupun eliminasi sarana prasarana. Sehingga keputusan 
evaluasi bisa ditentukan penambahan maupun kekurangan serta perawatan sarana prasarana yang dimiliki lembaga PAUD tersebut. Pelaksana evaluasi juga dapat dilakukan oleh badan pemerintah yang ditunjuk seperti BAN-S/M, yaitu untuk membantu sekolah dalam akreditasi dan melihat kemajuan yang telah dicapai disesuaikan dengan standar nasional pendidikan. Untuk sekolah yang sudah maju dapat memanfaatkan lembaga eksternal yang memiliki kapabilitas sebagai asesor seperti lembaga penyedia ISO.

\section{METODOLOGI PENELITIAN}

Adapun jenis penelitian yang digunakan dalam evaluasi pemenuhan standar minimal sarana dan prasarana di lembaga PAUD ini adalah dengan kualitatif deskriptif. Model evaluasi yang digunakan adalah model evaluasi ketimpangan. Model evaluasi ketimpangan atau lebih dikenal dengan the discrepancy evaluation model. Pemilihan subyek dalam penelitian ini menggunakan purposive sampling, dilanjutkan dengan menggunakan Snow Ball Sampling (Patilima, 2010), yaitu pemilihan sample dengan pertimbangan 1) subyek penelitian adalah anak usia dini yang terlibat langsung dalam proses pembelajaran, 2) informan dalam penelitian ini merupakan dokumen analisis. Penggalian informasi pada penelitian ini menggunakan langkah langkah tersebut antara lain: menetapkan desain program, merencanakan evaluasi, menggunakan model discrepancy, mengumpulkan data di lapangan mengidentifikasi kesenjangan, mengubah kondisi program dan/atau mengubah standar.

\section{HASIL DAN PEMBAHASAN}

Menurut panduan Pengelola Taman Kanak-kanak yang dikeluarkan oleh Departemen Pendidikan Nasional pada tahun 2006, sarana prasarana di Taman Kanak-Kanak juga berfungsi bagi perkembangan anak, diantaranya:

a. Menciptakan situasi belajar sambil bermain yang menyenangkan bagi anak untuk melakukan berbagaikegiatan.

b. Menimbulkan rasa percaya diri pada anak.

c. Membantu anak dalam pembentukan perilaku dan pengembangan kemampuan.

d. Memperkecil dan menghilangkan kebiasaan-kebiasaan anak yang kurang baik.

e. Memberikan kesempatan pada anak untuk bersosialisasi dan berkomunikasi atau berinteraksi dengan lingkungannya.

f. Membiasakan anak berperilaku disiplin dan bertanggungjawab.

Oleh sebab itu dapat membuktikan bahwa sarana prasarana di PAUD sangat diperlukan. Karena sarana prasarana digunakan oleh guru dan anak dalam proses belajar mengajar. Guru akan lebih mudah untuk memberikan pemahaman kepada anak sedangkan anak dapat memanfaatkan sarana dan prasarana untuk mengembangkan aspek perkembangan anak usia dini.

Pengelolaan sarana prasarana PAUD mencakup aset-aset yang di miliki oleh lembaga PAUD itu sendiri yaitu diantaranya sebagai berikut :

\section{Lokasi Pendirian PAUD}

Dalam merencanakan pengadaan lahan untuk gedung sekolah perlu mempertimbangkan hal berikut.

a. Membuat perencanaan tanah, luas, dan lokasi yang sesuai dengan kebutuhan.

b. Melakukan survei menentukan lokasi tujuan dan perencanaan tata kota.

c. Melakukan survei intuk melihat kondisi jalan, transportasi, air, dan listrik.

d. Harga tanah.

Bangunan sekolah yang ideal adalah dengan memenuhi kriteria berikut.

1. Memenuhi kcbutuhan dan syarat pedagogis, artinya:

a. Ukuran dan bentuk setiap ruangan disesuaikan dengan kebutuhan

b. Datangnya dan masuknya sinar matahari harus dari sebelah kiri 
c. Tinggi rendahnya tembok, letak kusen dan jendela disesuaikan dengan kondisi anak

d. Penggunaan warna yang cocok.

2. Aman, artinya bangunan memiliki pondasi yang kokoh.

3. Memiliki ruangan yang terdapat fentilasi sehingga udara dan cahaya dapat masuk ke dalam ruangan kelas. Sehingga anak dapat nyaman dan menyenangkan saat belajar.

4. Fleksibel, artinya sarana dan prasarana dapat diubah-ubah sesuai kondisi yang terjadi.

5. Memiliki lingkungan yang asri dan sejuk.

6. Ekonomis, artinya luas ruangan dapat dipergunakan untuk kebutuhan belajar. Seperti membuat taman sayur sekolah.

Ketersediaan Sarana Prasarana di Taman Kanak-kanak

Berdasarkan NSPK (Norma, Standar, Prosedur, dan Kriteria) Tentang Petunjuk Pelaksanaan Program Kanak-Kanak yang dikeluarkan oleh Kementerian Pendidikan dan Kebudayaan Republik Indonesia Tahun 2013, persyaratan atau standar sarana prasarana Taman Kanak-Kanak adalah sebagai berikut:

a. Luas lahan sekurang-kurangnya $300 \mathrm{~m} 2$

b. Memiliki ruang bermain/ruang belajar dengan rasio sekurang-kurangnya $3 \mathrm{~m} 2$ per anak, baik di dalam ataupun di luar ruangan.

c. Memiliki ruang kepala sekolah, guru, layanan kesehatan/UKS, toilet dengan air bersih, dan ruang lainnya yang relevan dengan kebutuhan kegiatan anak.

d. Memiliki perabot, alat peraga dan alat permainan di luar dan di dalam ruangan.

e. Memiliki tempat untuk memajang hasil karya anak yang ditata sejajar dengan pandangan anak, leluasa, tidak terlalu penuh dengan alat permainan (masih ada ruang kosong untuk gerak anak).

f. Penataan ruangan sesuai fungsinya, berikut perabot yang bersih dan terawat.

g. Bangunan gedung, sekurang-kurangnya memiliki:

\begin{tabular}{|c|l|c|c|c|}
\hline No & \multicolumn{1}{|c|}{ Jenis Ruang } & $\begin{array}{c}\text { Jumlah } \\
\text { Ruang }\end{array}$ & Ukuran Ruang & $\begin{array}{c}\text { Luas } \\
\text { Seluruhnya }\end{array}$ \\
\hline 1 & Ruang Kelas & 2 & $6 \times 6 \mathrm{~m} 2$ & $36 \mathrm{~m} 2$ \\
\hline 2 & $\begin{array}{l}\text { Ruang Kantor/Kepala } \\
\text { TK }\end{array}$ & 1 & $4 \times 3 \mathrm{~m} 2$ & $12 \mathrm{~m} 2$ \\
\hline 3 & Ruang Dapur & 1 & $2 \times 3 \mathrm{~m} 2$ & $6 \mathrm{~m} 2$ \\
\hline 4 & Gudang & 1 & $2 \times 3 \mathrm{~m} 2$ & $6 \mathrm{~m} 2$ \\
\hline 5 & Kamar Mandi/WC Guru & 1 & $2 \times 2 \mathrm{~m} 2$ & $4 \mathrm{~m} 2$ \\
\hline 6 & $\begin{array}{l}\text { Kamar Mandi/WC } \\
\text { Anak }\end{array}$ & 1 & $2 \times 2 \mathrm{~m} 2$ & $4 \mathrm{~m} 2$ \\
\hline 7 & Ruang Guru Kesehatan & 1 & $4 \times 5 \mathrm{~m} 2$ & $20 \mathrm{~m} 2$ \\
\hline 8 & $\begin{array}{l}\text { Usaha } \\
\text { Sekolah (UKS) }\end{array}$ & $3 \times 2 \mathrm{~m} 2$ & 6 \\
\hline
\end{tabular}

Tabel. 1 Standar Ruang di Taman Kanak-Kanak

Pelaksanaan evaluasi sarana prasarana sekolah dapat dilakukan dengan langkahlangkah sebagai berikut:

1. Menginventarisasi keberadaan sarana dan prasarana yang ada di sekolah, baik dalam hal kondisi, jumlah, spesifikasi, maupun data lain yang diperlukan.

2. Mengumpulkan data pendukung yang diperlukan seperti tanggal pengadaan, sumber pengadaan ataupun tanggapan pengguna sarana prasarana

3. Mengisi formulir evaluasi yang tersedia sesuai dengan kondisi yang sebenarnya

4. Merakapitulasi hasil evaluasi, baik data kualitatif maupun kuantitatif 
5. Menarik kesimpulan mengenai keseluruhan sarana prasarana sekolah, apakah sudah memenuhi standar minimal atau belum.

6. Melaporkan hasil evaluasi kepada pihak-pihak yang memerlukan

Dari analisis lapangan yang ditemukan di PAUD Cerdas Ceria Hutaraja masih sangat minim permainan edukatif dan yang paling penting adalah kelengkapan dari sarana dan prasarana harus melakukan evaluasi pemenuhan standar minimal sarana dan prasarana pendidikan anak usia dini. Dari segi prasarana yang belum tepat (kurang nyaman digunakan saat belajar ruang belajar, luas ruang bermain baik di luar maupun di dalam masih harus dilakukan perbaikan, ruang perpustakaan tidak ada, dan tidak memiliki ruang-ruang lain sebagai tempat belajar dan berkreasi anak, termasuk di dalamnya pekarangan, parit/got/selokan, WC juga maasih dalam kondisi yang belum dapat dikatakan baik. Tidak memiliki kolam renang maupun fasilitas lain yang mendukung pembelajaran) darisegi sarana juga PAUD Cerdas Ceria masih minim kelengkapannya. Contohnya buku yang digunakan sebagai media untuk belajar masih terbatas, perabotan sekolah juga masih tidak lengkap seperti meja dan kursi yang tidak menarik, alat peraga dan media pembelajaran juga kurang. Guru kurang kreatif untuk membuat media pembelaran dari bahan-bahan yang ada di sekitar untuk melengkapi kekurangan media pembelajaran dan alat peraga. APE dalam lembaga PAUD ini juga dapat dikatakan masih kurang memadai. Oleh karena itu kepala sekolah saat diwawancarai mengatakan bahwa mereka membutuhkan perhatian dari pemerintah maupun orang-orang yang sadar akan pentingnya pendidikan, yang rela untuk membantu mereka untuk meningkatkan kualitas sarana dan prasarana di lembaga PAUD tersebut.

\section{SIMPULAN}

Dapat disimpulkan bahwa sarana dan prasarana yang dimiliki oleh PAUD Cerdas Ceria sangat membutuhkan perhatian dan harus melakukan evaluasi pemenuhan standar minimal pemenuhan sarana dan prasarana pendidikan anak usia dini. Baik dilakukan secara mandiri maupun dibantu oleh pemerintah. Kegiatan evaluasi dapat menunjukkan tingkat penncapaian anak dalam mengembangkan aspek perkembangan anak usia dini. Sarana dan prasarana yang telah melalui evaluasi akan lebih baik. Karena sudah di bedakan yang mana sarana dan prasarana yang memiliki nilai edukatif yang tinggi dengan yang mana sarana prasarana yang kurang efektif dan kurang bermanfaat bagi pendidikan anak usia dini. Model evaluasi sarana dan prasarana yang dapat digunakan adalah model discrepancy adalah model evaluasi dengan cara membandingkan antara apa yang diharapkan (standard) dengan apa yang terjadi di lapangan (performance) sehingga dapat ditemukan kesenjangan/ketimpangan (discrepancy) yang kemudian dari hasil tersebut dapat dilakukan perbaikan-perbaikan. Langkah-langkah untuk melakukan kegiatan evaluasi adalah menetapkan desain program, merencanakan evaluasi menggunakan model discrepancy, mengumpulkan data di lapangan, mengidentifikasi kesenjangan, mengubah dan memperbaki kondisi program.

\section{DAFTAR PUSTAKA}

Anggani, Sudono. "Alat Permainan dan Sumber Belajar TK". Jakarta: Dirjen PPTA Depdikbud. 1995

Arikunto, S . (1988). "Evaluasi Program. Jakarta”, P2LPTK.

Bafadal, Ibrahim. 2004. "Manajemen Perlengkapan Sekolah”. Jakarta: Bumi Aksara 
Cucu Eliyawati. 2005. "Pemilihan dan Pengembangan Sumber Belajar". Jakarta. Direktorat Pembinaan Pendidikan.

El-Khuluqo, Ihsana. 2015. "Manajemen PAUD (Pendidikan Anak Usia Dini): Pendidikan Taman Kehidupan Anak". Yogyakarta: Pustaka Pelajar.

Musfiroh, Tadkiroatun. 2005. "Bermain Sambil Belajar dan Mengasah Kecerdasan". Jakarta. Depdiknas

S.Eko Putro Widoyoko. 2009. "Evaluasi Program Pembelajaran”.Yogyakarta ; Pustaka Belajar.

Slamet Suyanto. 2005. "Dasar-Dasar Pendidikan Anak Usia Dini”. Yogyakarta : Hikayat Publising

Sugiyono. (2007). "Metode Penelitian Pendidikan: Pendekatan Kuantitatif”, Kualitatif dan R\&D. Bandung: Alfabeta.

Suyadi. 2011. "Panduan Penelitian Tindakan Kelas Buku Panduan Wajib bagi Para Pendidik". Yogyakarta: DIVA Press.

Usman, U. (2002). “Menjadi Guru Profesional. Bandung”: PT. Remaja Rosdakarya

Rodah, Pelagia. Dkk. "Jurnal Manajemen Sarana Prasarana Pendidikan Anak Usia Dini di Taman Kanak-kanak". 